\title{
Effects of tetrandrine on calcium and potassium currents in isolated rat hepatocytes
}

\author{
Hong-Yi Zhou, Fang Wang, Lan Cheng, Li-Ying Fu, Ji Zhou, Wei-Xing Yao
}

Hong-Yi Zhou, Fang Wang, Lan Cheng, Li-Ying Fu, Ji Zhou, Wei-Xing Yao, Department of Pharmmacology, Tongji medical college of Huazhong university of science and technology, Wuhan 430030, Hubei Province, China

Correspondence to: Hong-Yi Zhou, Department of Pharmmacology, Tongji medical college of Huazhong university of science and technology, 13 hangkong Road,Wuhan 430030, China. zhouhy518@yahoo.com.cn Telephone: $027-83644206$

Received: 2002-06-27 Accepted: 2002-07-25

\begin{abstract}
AIM: To study the effects of tetrandrine (Tet) on calcium release-activated calcium current $\left(I_{\text {CRAC }}\right)$, delayed rectifier potassium current $\left(I_{K}\right)$, and inward rectifier potassium currents $\left(I_{K 1}\right)$ in isolated rat hepatocytes.
\end{abstract}

METHODS: Hepatocytes of rat were isolated by using perfusion method. Whole cell patch-clamp techniques were used in our experiment.

RESULTS: The peak amplitude of $I_{\text {CRAC }}$ was $-508 \pm 115$ pA $(n=15)$, its reversal potential of $I_{\text {CRAC }}$ was about $0 \mathrm{mV}$. At the potential of $-100 \mathrm{mV}$, Tet inhibited the peak amplitude of $\mathrm{I}_{\text {CRAC }}$ from $-521 \pm 95$ pA to $-338 \pm 85 \mathrm{pA}$ ( $\mathrm{P}<0.01$ vs control, $\mathrm{n}=5)$, with the inhibitory rate of $35 \%$ at $10 \mu \mathrm{mol} / \mathrm{L}$ and from $-504 \pm 87 \mathrm{pA}$ to $-247 \pm 82 \mathrm{pA}(\mathrm{P}<0.01$ vs control, $\mathrm{n}=5)$, with the inhibitory rate of $49 \%$ at $100 \mu \mathrm{mol} / \mathrm{L}$, without affecting its reversal potential. The amplitude of $I_{\text {CRAC }}$ was dependent on extracellular $\mathrm{Ca}^{2+}$ concentration. The peak amplitude of $I_{\text {CRAC }}$ was $-205 \pm 105$ pA $(n=3)$ in tyrode' s solution with $\mathrm{Ca}^{2+} 1.8 \mathrm{mmol} / \mathrm{L}(\mathrm{P}<0.01$ vs the peak amplitude of $\mathrm{I}_{\text {CRAC }}$ in external solution with $\left.\mathrm{Ca}^{2+} 10 \mathrm{mmol} / \mathrm{L}\right)$. Tet at the concentration of 10 and $100 \mu \mathrm{mol} / \mathrm{L}$ did not markedly change the peak amplitude of delayed rectifier potassium current and inward rectifier potassium current ( $P>0.05$ vs control).

CONCLUSION: Tet protects hepatocytes by inhibiting $I_{\text {CRAC, }}$ which is not related to $\mathrm{I}_{\mathrm{K}}$ and $\mathrm{I}_{\mathrm{K} 1}$.

Zhou HY, Wang F, Cheng L, Fu LY, Zhou J, Yao WX. Effects of tetrandrine on calcium and potassium currents in isolated rat hepatocytes. World J Gastroenterol 2003; 9(1): 134-136 http://www.wjgnet.com/1007-9327/9/134.htm

\section{INTRODUCTION}

Tetrandrine (Tet) is a bisbenzylisoquinoline alkaloid from a Chinese medicinal herb (stephania tetrandra S. Moore). In the past decade, lots of studies demonstrated that Tet possessed multiple bioactivities, such as potential immunomodulating, anticarcinoma ${ }^{[1]}$ and protective effect on $\mathrm{CCl}_{4}$-injured hepatocytes ${ }^{[2]}$. It has also been used in the treatment of ischemic heart diseases ${ }^{[3]}$ and hypertension ${ }^{[3,4]}$. Recently, the antifibrotic effects of Tet have been received considerable attention ${ }^{[1,5-10]}$. The former researches of Tet on the liver have probed into cellular and molecular levels ${ }^{[9,10]}$. In the present paper, we used whole-cell patch-clamp technique to observe the effects of Tet on $I_{\mathrm{CRAC}}, I_{\mathrm{K}}, I_{\mathrm{K} 1}$ in normal isolated rat hepatocytes, in order to have a better understanding its hepatoprotective and antifibrotic effects.

\section{MATERIALS AND METHODS \\ Solutions and drugs}

Tet was from Jinhua Pharmaceutical Co. The stock solution $(10 \mathrm{mmol} / \mathrm{L})$ was dissolved in distilled water after acidification with $0.1 \mathrm{~mol} / \mathrm{L} \mathrm{HCl}$ and neutralized with $0.1 \mathrm{~mol} / \mathrm{L} \mathrm{NaOH}$. $\mathrm{Ca}^{2+}$-free Hank' s solution was prepared without $\mathrm{Ca}^{2+}$ and $\mathrm{Mg}^{2+}$. $\mathrm{KB}$ solution contained ( $\mathrm{mmol} / \mathrm{L})$ : glutamic acid 70, taurine $15, \mathrm{KCl} 130, \mathrm{KH}_{2} \mathrm{PO}_{4} 10$, HEPES 10 , glucose 11 , egtazic acid 0.5 , $\mathrm{pH}$ was adjusted to 7.4 with $\mathrm{KOH}$. The external solution used to record Icrac contained (mmol/L): $\mathrm{NaCl} 140, \mathrm{KCl} 2.8$, $\mathrm{CaCl}_{2} 10, \mathrm{MgCl}_{2}$ 0.5, glucose 11, HEPES 10, $\mathrm{pH}$ was adjusted to 7.4 with $\mathrm{NaOH}$. The internal solution used to record $\mathrm{I}_{\mathrm{CRAC}}$ contained (mmol/L): potassium-glutamate $145, \mathrm{NaCl} 8, \mathrm{MgCl}_{2}$ $1, \mathrm{Mg}$-ATP 0.5 , egtazic acid 10, HEPES $10, \mathrm{pH}$ was adjusted to 7.2 with $\mathrm{KOH}$. The external solution used to record $\mathrm{I}_{\mathrm{K}}$ contained (mmol/L): $\mathrm{NaCl} 144, \mathrm{KCl} 4, \mathrm{CaCl}_{2} 1.8, \mathrm{MgCl}_{2} 0.53$, $\mathrm{NaH}_{2} \mathrm{PO}_{4} 0.33$, glucose 5.5, HEPES 5, $\mathrm{pH}$ was adjusted to 7.4 with $\mathrm{NaOH}$. The internal solution used to record $\mathrm{I}_{\mathrm{K}}$ contained (mmol/L): $\mathrm{KCl} 130, \mathrm{~K}_{2} \mathrm{ATP} 5$, creatine phosphate 5, HEPES $5, \mathrm{pH}$ was adjusted to 7.2 with $\mathrm{KOH}$. The same external and internal solutions used to record $\mathrm{I}_{\mathrm{K} 1}$ contained $(\mathrm{mmol} / \mathrm{L}): \mathrm{KCl}$ $7, \mathrm{MgCl}_{2} 2$, egtazic acid 1, potassium-glutamate 130, HEPES $10, \mathrm{pH}$ was adjusted to 7.4 with $\mathrm{KOH}$.

\section{Isolation of single hepatocytes}

Hepatocytes were isolated with the modified method reported by Seglen ${ }^{[11]}$. Briefly, adult wistar rats of either sex $(175 \pm 25 \mathrm{~g})$ were anesthetized by intraperitoneal injection of pentobarbital sodium $(50 \mathrm{mg} / \mathrm{kg})$. The portal vein was cannulated and perfused with oxygenated $\mathrm{Ca}^{2+}$-free Hank' s solution $30 \mathrm{ml} /$ min at $37{ }^{\circ} \mathrm{C}$ for $4-5$ min followed by perfusion with $\mathrm{Ca}^{2+}$-free Hank' s solution containing collagenase (Type 1, Sigma) (0.3g/ $\mathrm{L}$ ) for $10 \mathrm{~min}$. The liver was chopped in $10 \mathrm{ml} \mathrm{Ca}^{2+}$-free Hank' s solution. The cell suspension was filtered through 200 mesh gauze and then centrifuged three times $(50 \mathrm{~g}, 2 \mathrm{~min})$ to separate liver cells. Cells were plated onto the coverslips and incubated in $\mathrm{KB}$ medium for 2 hour and preserved in DMEM at $4{ }^{\circ} \mathrm{C}$.

\section{Electrophysiologic recording}

Whole-cell recordings were performed using an PC-II patch clamp amplifier (Huazhong university of science and technology). The recording chamber $(1.5 \mathrm{ml})$ was perfused with the corresponding external solution. The pipettes were pulled in two stages from hard glass capillaries using a vertical microelectrode puller (Narishige, Japan). Electrode has a resistance of 2-5M $\Omega$ for whole-cell recording when filled with electrode internal solution. All experiments were conducted at $22 \pm 2{ }^{\circ} \mathrm{C}$.

\section{Statistic analysis}

The data were expressed as $\bar{x} \pm s$. Statistical significances were analyzed by a unpaired $t$-test. A value of $P<0.05$ was considered significant. 


\section{RESULTS}

\section{Effect of Tet on calcium release-activated calcium current (I I CRAC)}

$\mathrm{I}_{\text {CRAC }}$ was elicited for $200 \mathrm{~ms}$ from the holding potential of $0 \mathrm{mV}$ to various potentials ranging from $-10 \mathrm{mV}$ to $+80 \mathrm{mV}$ with the step of $20 \mathrm{mV}$ every $5 \mathrm{~s}^{[12]}$. The peak amplitude of $\mathrm{I}_{\mathrm{CRAC}}$ was $508 \pm 115 \mathrm{pA}(n=15)$ and the reversal potential of $\mathrm{I}_{\text {CRAC }}$ Was about $0 \mathrm{mV}$, the current was steady and without run-down in 5 mins. Tet inhibited the peak amplitude of $\mathrm{I}_{\mathrm{CRAC}}$ from $-521 \pm 95$ pA to $-338 \pm 85 \mathrm{pA}(P<0.01 v s$ control, $n=5)$, with the inhibitory rate of $35 \%$ at $10 \mu \mathrm{mol} / \mathrm{L}$ and from $-504 \pm 87 \mathrm{pA}$ to $-247 \pm 82$ pA $(P<0.01 v s$ control, $n=5)$, with the inhibitory rate of $49 \%$ at $100 \mu \mathrm{mol} / \mathrm{L}$. Tet did not affect the shape of its current voltage curve (Figure 1,2).

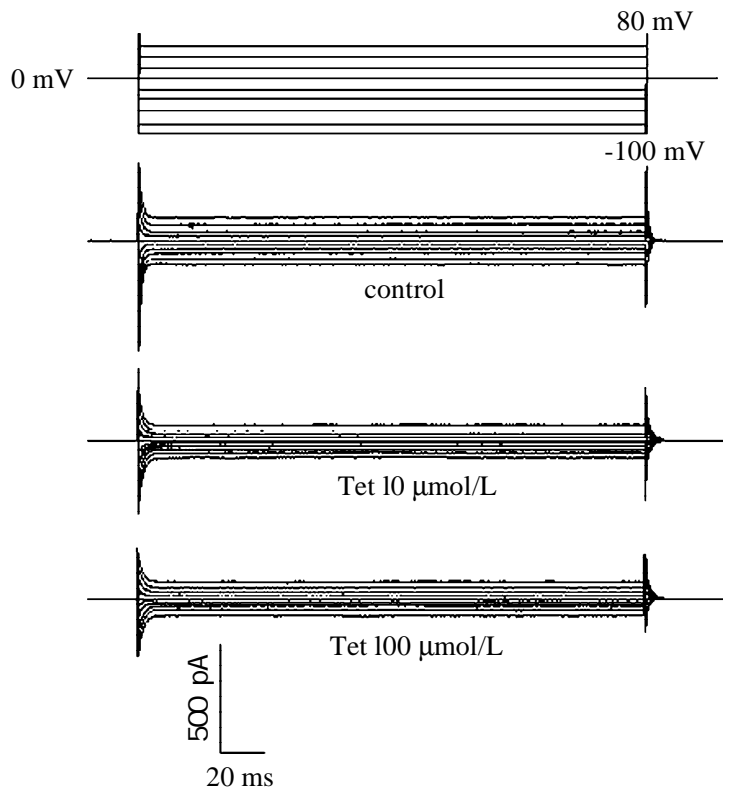

Figure 1 Effect of Tet on $I_{\text {CRAC }}$ in isolated rat hepatocytes. $I_{\text {CRAC }}$ traces beforeand after Tet $10 \mu \mathrm{mol} / \mathrm{L}$ and $100 \mu \mathrm{mol} / \mathrm{L}$. I IRAC WaS elicited for $200 \mathrm{~ms}$ from the holding potential of $0 \mathrm{mV}$ to various potentials ranging from $-100 \mathrm{mV}$ to $+80 \mathrm{mV}$ with step of $20 \mathrm{mV}$.

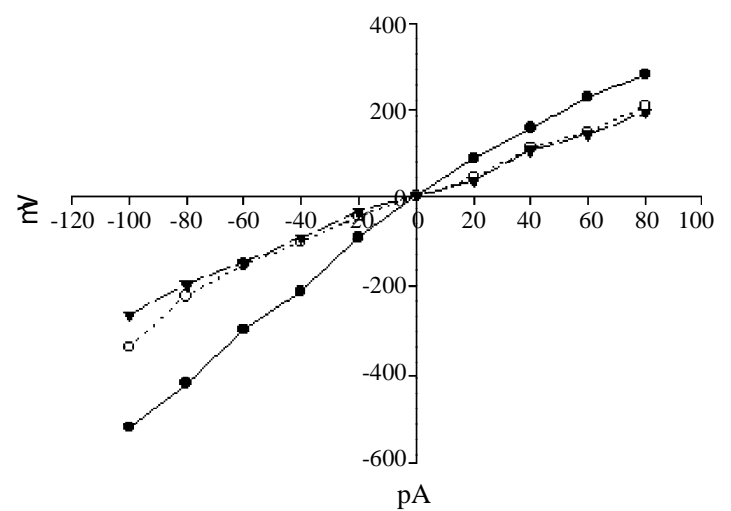

Figure 2 Effect of Tet on I-V relationship of $I_{C R A C}$ in isolated rat hepatocytes. Especially at the potential of $-100 \mathrm{mV}$, Tet inhibited the peak amplitude of $I_{\text {CRAC }}$ with the inhibitory rate of $35 \%$ at $10 \mu \mathrm{mol} / \mathrm{L}$ and with the inhibitory rate of $49 \%$ at $100 \mu \mathrm{mol} / \mathrm{L}$. - control; $\bigcirc 10 \mu \mathrm{mol} / \mathrm{L}$; $\boldsymbol{\nabla} 100 \mu \mathrm{mol} / \mathrm{L}$.

The amplitude of $\mathrm{I}_{\mathrm{CRAC}}$ was dependent on extracellular $\mathrm{Ca}^{2+}$ concentration. The peak amplitude of $\mathrm{I}_{\mathrm{CRAC}}$ was $-205 \pm 105 \mathrm{pA}$ $(n=3)$ in tyrode' s solution with $\mathrm{Ca}^{2+} 1.8 \mathrm{mmol} / \mathrm{L}(P<0.01 \mathrm{vs}$ the peak amplitude of $\mathrm{I}_{\mathrm{CRAC}}$ in external solution with $\mathrm{Ca}^{2+} 10$ $\mathrm{mmol} / \mathrm{L})$. Tet at $10 \mu \mathrm{mol} / \mathrm{L}$ decreased $\mathrm{I}_{\mathrm{CRAC}}$ from $-205 \pm 105$ pA to $-148 \pm 96 \mathrm{pA}(n=3)$.

\section{Effect of Tet on delayed rectifier potassium current $\left(I_{K}\right)$}

$\mathrm{I}_{\mathrm{K}}$ was elicited by $900 \mathrm{~ms}$ depolarization steps from $+30 \mathrm{mV}$ to $+140 \mathrm{mV}$ with step of $10 \mathrm{mV}$ at holding potential of $-50 \mathrm{mV}^{[13]}$. Tet at 10 and $100 \mu \mathrm{mol} / \mathrm{L}$ did not change the peak amplitude of $\mathrm{I}_{\mathrm{K}}$ [from $2014 \pm 686 \mathrm{pA}$ to $2030 \pm 692 \mathrm{pA}$ and $2047 \pm 710 \mathrm{pA}$ respectively, $n=5$, cells from 3 rats, $P>0.05]$. Tet did not affect the shape of its current voltage curve.

\section{Effect of Tet on inward rectifier potassium current $\left(I_{K_{1}}\right)$}

$\mathrm{I}_{\mathrm{K} 1}$ was elicited by a number of step pulses $(40 \mathrm{~ms})$ from the holding potential $(\mathrm{Eh})$ of $0 \mathrm{mV}$ to test potentials from -200 $\mathrm{mV}$ to $+175 \mathrm{mV}$ with the step of $10 \mathrm{mV}^{[14]}$. Tet at 10 and 100 $\mu \mathrm{mol} / \mathrm{L}$ did not change the peak amplitude of $\mathrm{I}_{\mathrm{K} 1}$ [from $2254 \pm 718 \mathrm{pA}$ to $2239 \pm 700 \mathrm{pA}$ and $2224 \pm 658 \mathrm{pA}$ respectively, $n=5$, cells from 3 rats, $P>0.05]$. Tet did not affect the shape of its current voltage curve.

\section{DISCUSSION}

Hepatic fibrosis is a common consequence of chornic liver injury from many cause ${ }^{[15-19]}$, and the sustained hepatic injury is a primary factor for hepatic fibrogenesis ${ }^{[20-28]}$. Preventing hepatocyte from injury is a matter of primary importance in blocking the fibrogenic pathway. Tet has been considered as an effective antifibrotic and hepatoprotective agent ${ }^{[1,2,5-10]}$, but its protection against toxic cell death has never been well illustrated.

The $\mathrm{Ca}^{2+}$ influx is mainly mediated by voltage-operated $\mathrm{Ca}^{2+}$ channels and receptor-activated $\mathrm{Ca}^{2+}$ channels. Voltageoperated $\mathrm{Ca}^{2+}$ channels are not present in hepatocytes ${ }^{[29]}$. Calcium influx in isolated hepatocytes mainly depend on receptor-mediated $\mathrm{Ca}^{2+}$ entry which has been identified by indirect methods ${ }^{[30]}$. Previous studies have shown that one type of receptor-activated $\mathrm{Ca}^{2+}$ channels, most likely a storeoperated $\mathrm{Ca}^{2+}$ channel, in freshly isolated rat hepatocytes is inhibited by high concentrations of L-type voltage-operated $\mathrm{Ca}^{2+}$ channels antagonists ${ }^{[30,31]}$. Besides, the mRNA encoding isoforms of L-type voltage-operated $\mathrm{Ca}^{2+}$ channels has been detected in rat hepatocytes, these observation suggested that receptor-activated $\mathrm{Ca}^{2+}$ channels in rat hepatocytes exhibit some characteristics of voltage-operated $\mathrm{Ca}^{2+}$ channels ${ }^{[32]}$. Cui et al reported that $\mathrm{I}_{\mathrm{CRAC}}$ (an important sub-type of store-operated $\mathrm{Ca}^{2+}$ channels) existed in isolated rat hepatocytes and $50 \mu \mathrm{mol} /$ $\mathrm{L}$ of verapamil, diltiazem and nifedipine could decrease the amplitude of $\mathrm{I}_{\mathrm{CRAC}}$ effectively ${ }^{[12]}$. The results in our experiment showed that Tet at the concentration of 10 and $100 \mu \mathrm{mol} / \mathrm{L}$ could decrease the peak amplitude of $I_{\mathrm{CRAC}}$. The concentration that Tet made a half-maximal inhibition of $\mathrm{I}_{\mathrm{CRAC}}$ was approximately $100 \mu \mathrm{mol} / \mathrm{L}$, which was substantially higher than that needed for the half-maximal inhibition of L-type voltage-operated $\mathrm{Ca}^{2+}$ channels by Tet. It suggested that Tet could protect hepatocytes by inhibiting $\mathrm{I}_{\mathrm{CRAC}}$ and decreasing intracellular $\mathrm{Ca}^{2+}$ concentration, in which a higher concentration of Tet was needed.

Nietsch's study demonstrated that the activation of potassium and chloride channels by TNF- $\alpha$ induced apoptosis and death of the HTC rat hepatoma cells, which could be significantly delayed by $\mathrm{K}^{+}$channel blockers $\left(\mathrm{Ba}^{2+}\right.$ and quinine) ${ }^{[33]}$. Our result showed that Tet had no effect on $\mathrm{I}_{\mathrm{K}}$ and $\mathrm{I}_{\mathrm{K} 1}$, which suggested that the hepatoprotection of Tet might not relate to potassium channels. However, whether calcium activated potassium channels exist in rat hepatocytes or not remains controversial ${ }^{[34,35]}$. The effect of Tet on potassium channels requires further investigation.

In conclusion, Tet protects hepatocytes by inhibiting $\mathrm{I}_{\mathrm{CRAC}}$, which is not related to $I_{K}$ and $I_{K 1}$.

\section{REFERENCES}

1 Li D G, Wang ZR, Lu HM. Pharmacology of tetrandrine and its therapeutic use in digestive diseases. W orld J Gastroenterol 2001; 7: $627-629$ 
2 Chen XH, Hu YM, Liao YQ. Protective effects of tetrandrine on CCl4-injured hepatocytes. A cta Pharmacol Sin 1996; 17: 348-350

3 Wong TM, Wu S, Yu XC, Li HY. Cardiovascular actions of Radix Stephaniae Tetrandrae: a comparison with its main component, tetrandrine. A cta Pharmacol Sin 2000; 21: 1083-1088

4 Cheng D, Chen W, Mo X. A cute effect of tetrandrine pulmonary targeting microspheres on hypoxic pulmonary hypertension in rats. Chin M ed J (Engl) 2002; 115: 81-83

5 Lee SH, Nan JX, Sohn DH. Tetrandrine prevents tissue inhibitor of metalloproteinase-1 messenger RNA expression in rat liver fibrosis. Pharmacol Toxicol 2001; 89: 214-216

6 Liu D, Li G, Liu D, Cao Y. Effects of tetrandrine on the synthesis of collagen and scar-derived fibroblast DNA. Z honghua Shaoshang Zazhi 2001; 17: 222-224

7 Park PH, Nan JX, Park EJ, Kang HC, Kim JY, Ko G, Sohn DH. Effect of tetrandrine on experimental hepatic fibrosis induced by bile duct ligation and scission in rats. Pharmacol Toxicol 2000; 87: 261-268

8 Ma JY, Barger MW, Hubbs AF, Castranova V, Weber SL, MaJK. Use of tetrandrine to differentiate between mechanisms involved in silica-versus bleomycin-induced fibrosis. J Toxicol Environ $H$ ealth A 1999; 57: 247-266

9 Li D G, Lu HM, Chen YW. Progression on antifibrotic effects of tetrandrine. Shijie H uaren Xiaohua Z azhi 1999; 7: 171-172

10 Li D G, Lu HM, Chen YW. Progress in studies of tetrandrine against hepatofibrosis. W orld J Gastroenterol 1998; 4: 377-379

11 Seglen PO. Preparation of isolated rat liver cells. M ethods Cell Biol 1976; 13: 29-83

12 Cui GY, Li JM, Cui H, Hao LY, Liu DJ, Zhang KY. Effects of calcium channel blockers on calcium release-activated calcium currents in rat hepatocytes. A cta Pharmacol Sin 1999; 20: 415-418

13 Li JM, Cui GY, Liu DJ, Cui H, Chang TH, Wang YP, Zhang KY. Effects of $\mathrm{N}$-methyl berbamine on delayed outward potassium current in isolated rat hepatocytes. A cta Pharmacol Sin 1998; 19: 24-26

14 Henderson RM , Graf J, Boyer J L. Inward-rectifying potassium channels in rat hepatocytes. A m J Physiol 1989; 256: G1028-1035

$15 \mathbf{W u} \mathbf{~ C H}$. Fibrodynamics-elucidation of the mechanisms and sites of liver fibrogenesis. W orld J Gastroenterol 1999; 5: 388-390

16 Albanis E, Friedman SL. Hepatic fibrosis. Pathogenesis and principles of therapy. Clin Liver D is 2001; 5: 315-334

17 Friedman SL. Molecular regulation of hepatic fibrosis, an integrated cellular response to tissue injury. J Biol Chem 2000; 275: 2247-2250

18 Brenner D A, Waterboer T, Choi SK, Lindquist JN, Stefanovic B, Burchardt E, Yamauchi M, Gillan A, Rippe RA. New aspects of hepatic fibrosis. I H epatol 2000; 32(Suppl 1): 32-38

19 M addrey WC. Alcohol-induced liver disease. Clin Liver D is 2000; 4: 115-131

20 Liu Y, Shimizu I, Omoya T, Ito S, Gu XS, Zuo J. Protection effect of estradiol on hepatocytic oxidative damage. W orld J Gastroenterol 2002; 8: 363-366

21 Wei HS, Li DG, Lu HM, Zhan YT, Wang ZR, Huang X, Zhang J, Cheng JL, Xu QF. Effects of AT1 receptor antagonist, losartan, on rat hepatic fibrosis induced by $\mathrm{CCl} 4$. W orld J Gastroenterol 2000; 6: 540-545

22 Hu YY, Liu CH, Wang RP, Liu C, Liu P, Zhu DY. Protective actions of salvianolic acid $A$ on hepatocyte injured by peroxidation in vitro. W orld J Gastroenterol 2000; 6: 402-404

23 Chen PS, Zhai WR, Zhou XM, Zhang JS, Zhang YE, Ling YQ, Gu $\mathrm{YH}$. Effects of hypoxia, hyperxia on the regulation of expression and activity of matrix metalloproteinase- 2 in hepatic stellate cells. W orld J Gastroenterol 2001; 7: 647-651

24 H amasaki K, Nakashima M, Naito S, A kiyama Y, Ohtsuru A, Hamanaka Y, Hsu CT, Ito M, Sekinel. The sympathetic nervous system promotes carbon tetrachloride-induced liver cirrhosis in rats by suppressing apoptosis and enhancing the growth kinetics of regenerating hepatocytes. J Gastroenterol 2001; 36: 111-120

25 H u Y, Wang R, Zhang X, Liu C, Liu C, Liu P, Zhu D. Effects of carbon tetrachloride-injured hepatocytes on hepatic stellate cell activation and salvianolic acid A preventive action in vitro. Zhonghua Ganzangbing Zazhi 2000; 8: 299-301

$26 \mathrm{Kim} \mathrm{KY}$, Choi I, Kim SS. Progression of hepatic stellate cell activation is associated with the level of oxidative stress rather than cytokines during CCl4-induced fibrogenesis. M ol Cells 2000; 10: 289-300

27 Shi J, Aisaki K, Ikawa Y, Wake K. Evidence of hepatocyte apoptosis in rat liver after the administration of carbon tetrachloride. A m J Pathol 1998; 153: 515-525

28 G reenwel $\mathbf{P}$, Dominguez-Rosales JA, Mavi G, Rivas-Estilla AM, Rojkind M. Hydrogen peroxide: a link between acetaldehyde elicited al phal (I) collagen gene up-regulation and oxidativestress in mouse hepatic stellate cells. H epatology 2000; 31: 109-116

29 Sawanobori T, Takanashi H, Hiraoka M, Iida Y, Kamisaka K, Maezawa $\mathrm{H}$. Electrophysiological properties of isolated rat liver cells. J Cell Physiol 1989; 139: 580-585

30 Striggow F, Bohnensack R. Verapamil and diltiazem inhibit receptor-operated calcium channels and intracellular calcium oscillations in rat hepatocytes. FEBS Lett 1993; 318: 341-344

31 Hughes BP, Milton SE, Barritt GJ, Auld AM. Studies with verapamil and nifedipine provide evidence for the presence in theliver cell plasma membrane of two types of $\mathrm{Ca}^{2+}$ inflow transporter which are dissimilar to potential-operated $\mathrm{Ca}^{2+}$ channels. Biochem Pharmacology 1986; 35: 3045-3052

32 Brereton H M, Harland ML, Froscio M, Petronijevic T, Barritt GJ. N ovel variants of voltage-operated calcium channel al pha 1-subunit transcripts in a rat liver-derived cell line: deletion in the IVSA voltage sensing region. Cell Calcium 1997; 22: 39-52

33 Nietsch H H, Roe MW, FiekersJF, Moore AL, Lidofsky SD. Activation of potassium and chloride channels by tumor necrosis Factor $\alpha$ role in liver cell death.J Biol Chem 2000; 275: 20556-20561

34 Takanashi H, Sawanobori T, Kamisaka K, Maezawa H, Hiraoka M. $\mathrm{Ca}^{2+}$-activated $\mathrm{K}^{+}$channel is present in guinea-pig but lacking in rat hepatocytes. Jpn J Physiol 1992; 42: 415-430

35 D uszynski J, Elensky M, Cheung JY, Tillotson DL, Lanoue KF. Hormone-regulated $\mathrm{Ca}^{2+}$ channel in rat hepatocytes revealed by whole cell patch clamp. Cell Calcium 1995; 18: 19-29 